\title{
Insulators in vertebrates: regulatory mechanisms and chromatin structure
}

\author{
S. V. Ulianov ${ }^{1,2}$, E. N. Markova ${ }^{1}$, A. A. Gavrilov ${ }^{1,3}$, S. V. Razin ${ }^{1,2}$ \\ ${ }^{1}$ Institute of Gene Biology, Russian Academy of Sciences \\ 34/5, Vavilova Str., Moscow, Russian Federation, 119334 \\ ${ }^{2}$ Department of Molecular Biology, Faculty of Biology, M. V. Lomonosov Moscow State University \\ Leninskie Gory, Moscow, Russian Federation, 119991 \\ ${ }^{3}$ University of Oslo, Centre for Medical Studies in Russia \\ 34/5, Vavilova Str., Moscow, Russian Federation, 119334 \\ sergey.v.razin@usa.net
}

\begin{abstract}
Insulators were first identified as genomic elements either blocking communication between promoters and enhancers (enhancer-blocking activity) or restricting heterochromatin spreading (barrier activity). There are several types of insulators in Drosophila which utilize different proteins. All insulators identified in vertebrates work with the help of the multifunctional transcription factor CTCF. Biological functions of vertebrate insulators are not clear yet. They are supposed to separate chromatin domains albeit there is almost none direct evidence of this fact. The most significant is the participation of insulators in maintenance of centers of imprinting (imprinting choice regions). The results of a number of recently published articles indicate that isolation of a gene by placement of this gene into a separate topological domain (loop) is crucial to establishing imprinting. In this particular case as well as in many other cases insulators serve as architectural elements supporting the threedimensional structure of genome. Moreover, interaction between pairs of insulators where cohesin plays a pivotal role along with CTCF folds genome into various loops.
\end{abstract}

Keywords: chromatin domain, barrier element, enhancer-blocking element, CTCF, imprinting.

Introduction. The term «insulator» stands for special genomic elements which provide functional isolation of different parts of genome. Classical insulators possess two different types of activities: enhancer-blocking (opposing the effect of enhancers on promoters placed behind insulators [1]) and barrier activity (preventing processive spreading of histone covalent modifications in chromatin [2,3]). At the same time there are deficient or incomplete insulators bearing only one type of the activities described above. Therefore, it is right to call them either enhancer-blocking or barrier elements. Unfortunately, not all authors follow this nomenclature. Consequently, in common literature the term «insulator» is frequently used for both enhancer-blocking elements without barrier activity and barrier elements lacking enhancer-blocking activity.

(C) Institute of Molecular Biology and Genetics, NAS of Ukraine, 2012
Insulators were first identified while studying the heat-shock gene locus of Drosophila melanogaster. This locus was shown to be flanked by special genomic elements (special chromosome structures, SCS elements) including regions hypersensitive to DNAse I [4]. It was later that SCS elements were shown to cut off the communication between enhancers and promoters [1]. This activity was called enhancer-blocking. A special enhancer-blocking assay is used for its detection. The principal of this method is depicted in Fig. 1. Being placed inside genome between enhancer and promoter of a reporter gene, enhancer-blocking element suppresses the activity of the enhancer upon the promoter. At the same time putting this element on the other side of the enhancer does not impose such effect on the reporter gene promoter activity (Fig. $1, A$ ). In a plasmid enhancer-blocking element is capable of disrupting the promoter-enhancer communication only in those cases 
$A$

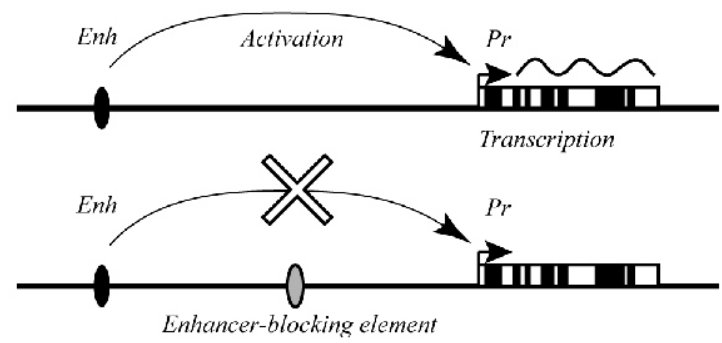

Enhancer-blocking element

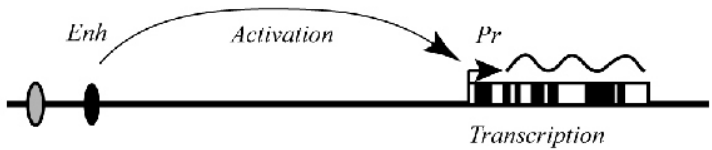

$B$

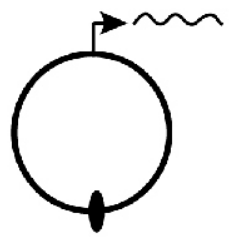

$\begin{array}{lllllllllllll}T & r & a & n & s & c & r & i & p & t & i & o & n\end{array}$

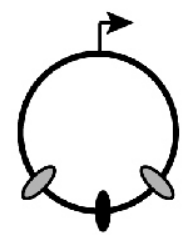

Promoter is inaclive

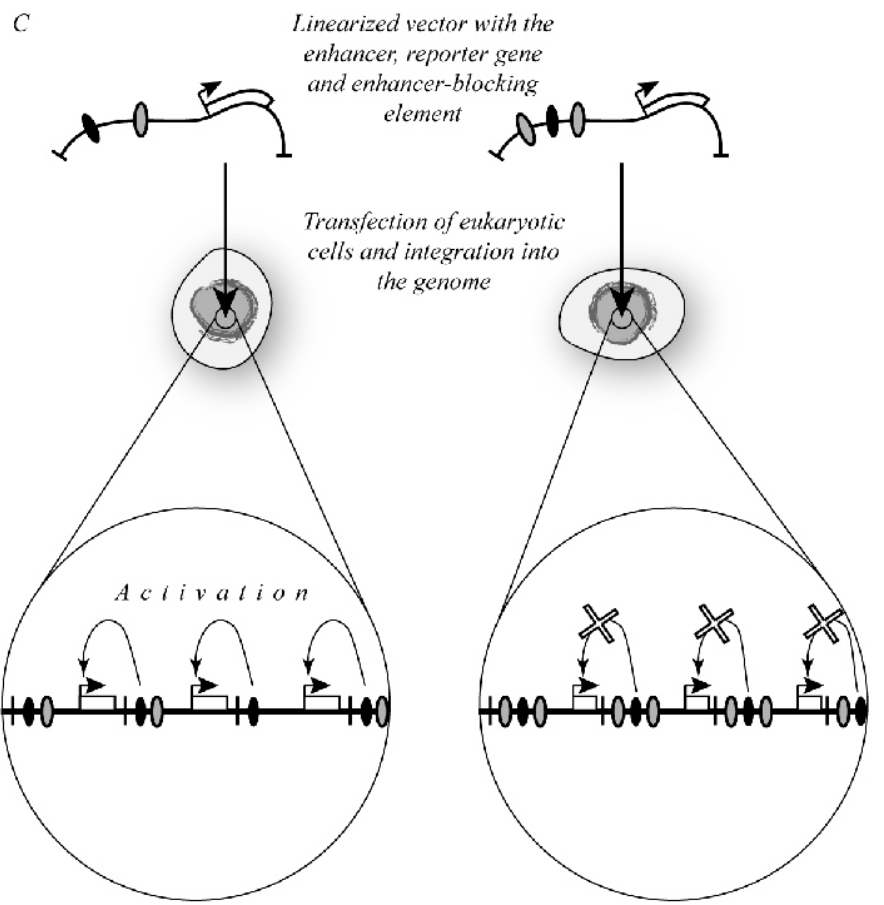

Fig. 1. Enhancer-blocking assay: $A$ - insulator blocks promoter activation by a distal enhancer in the genome only if it is located between the promoter and the enhancer; $B$ - in a plasmid only two copies of insulator flanking an enhancer are able to suppress activation of the reporter gene promoter by the enhancer; $\mathrm{C}$ - there is a similar situation in transgenes, produced using transfection of linearized constructs

when two copies of it flank enhancer [5] (Fig. 1,B). This is the key difference between the enhancer-blocking element and silencer which on the contrary suppresses the enhancer activity despite its position relative to the effected gene. Along with enhancer-blocking activity SCS-elements possess barrier activity preventing the spreading of inactive chromatin domains (heterochromatin). A reporter gene surrounded by SCS-elements works normally even when the construct is integrated into the pericentromeric region [2].

The following research elucidated that genomes of all studied groups of eukaryotes from yeast to humans contain insulators (both complete as well as deficient with either enhancer-blocking or barrier activities) [610]. However, no consensus motives were identified inside the insulator sequences of different taxonomic groups [11].

Insulator of the chicken $\beta$-globin gene domain. One of the most studied vertebrate insulators is the insulator located at the 5 '-end of the locus control region
(LCR) of the chicken $\beta$-globin gene domain which colocalizes with DNAse I hypersensitive site 4 (DHS4, see Fig. 2). This insulator is complete which means that it has both enhancer-blocking and barrier activities [12-15]. It was the first insulator to be identified in vertebrates. Its properties were comprehensively characterized with the help of transgenic experiments as well as transient transfection of both vertebrate and invertebrate cell lines. The minimal fragment of DNA possessing insulator activity (core element) and colocalizing with DHS4 is about $250 \mathrm{bp}$ in size and it represents a CpGisland which has a remote structural resemblance to the promoters of house-keeping genes [16]. An additional fragment of $400 \mathrm{bp}$ adjoining the core element at the 3'end is required to display the full insulator activity [17]. Within the sequence of the minimal insulator five different protein binding sites were identified [16]. One of these sites (so called footprint II, FII in experiments of Reitman and Felsenfeld [18]) is necessary and sufficient for enhancer-blocking activity. This site binds the 


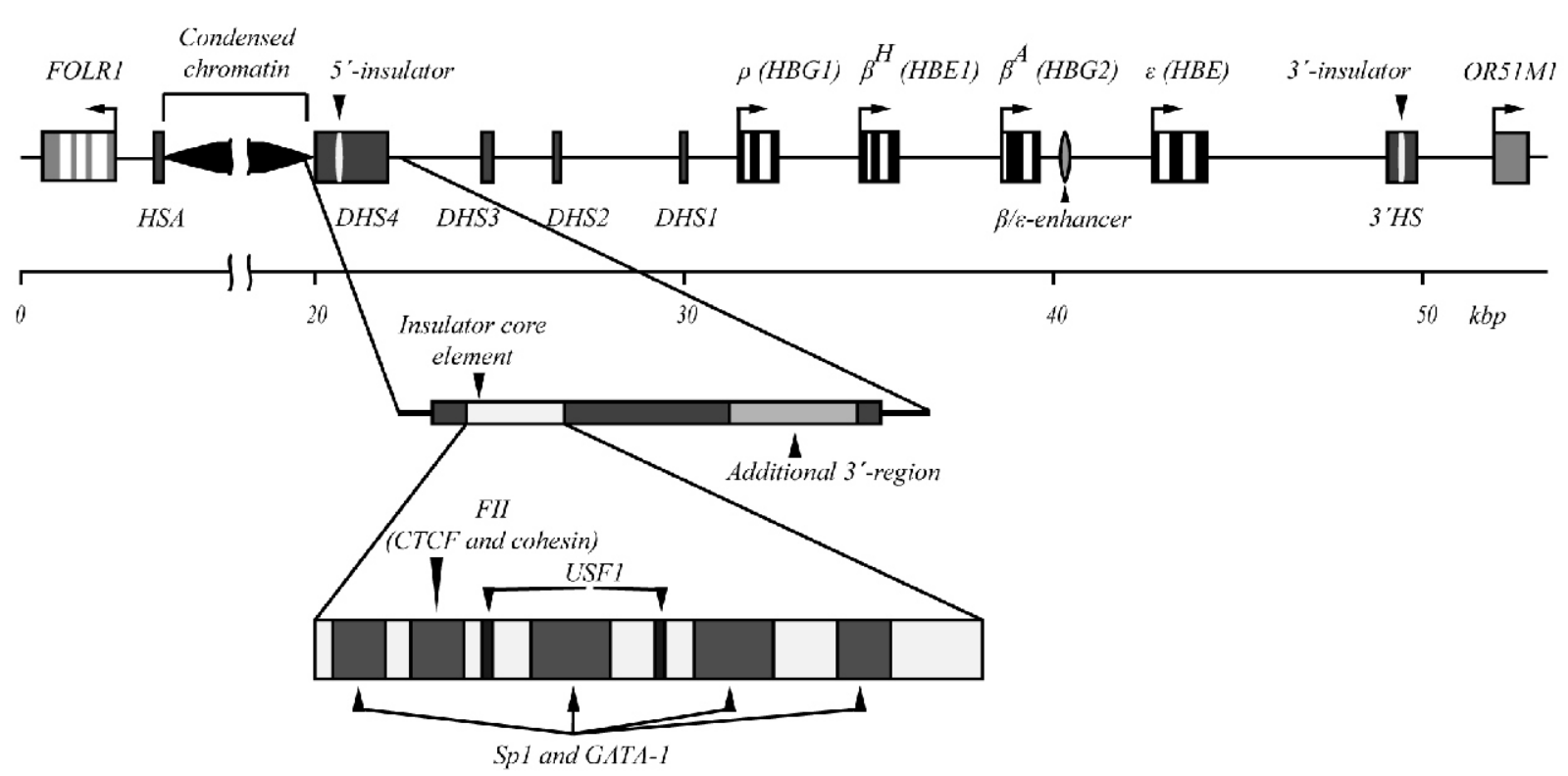

Fig. 2. Chicken beta-globin gene domain and its 5'-boundary insulator. FOLR1-gene encoding the folate receptor transcribed in earlier erythroid progenitors; HSA - erythroid -specific DNAse I-hypersensitive site; DHS1-3 - locus control region of the beta-globin gene domain; OR51M1 - a gene encoding an odorant receptor

multifunctional transcription factor CTCF [19]. Deletion of FII leads to the loss of enhancer-blocking activity of the insulator. The studies of the last few years show that cohesin as well as CTCF is indispensable for the activity of enhancer-blocking elements. The CTCF binding site overlaps with the site which binds cohesin. Knockdown of either CTCF or cohesin leads to the loss of enhancer-blocking activity of DHS4 [20]. It was demonstrated that direct physical interaction between CTCF and cohesion is needed for enhancer-blocking activity [21].

Barrier activity of the DHS4 insulator is retained after deletion of the CTCF binding site [19]. It means that barrier and enhancer-blocking activities are provided by different structural elements of the DHS4 insulator and that barrier activity is supported by proteins other than CTCF [14]. In particular barrier activity is performed with the help of protein USF1 (Fig. 3) which binds to insulators and recruits complexes of H3K4- and H4R3specific histone methyltransferases, histone acetyltransferases and chromatin remodeling complexes [22, 23].

Other vertebrate insulators. CTCF-dependent enhancer-blocking elements were identified in human and murine $\beta$-globin gene domains. They are located approximately in the same place as in the chicken $\beta$-globin gene domain i. e. at the 5'-end of the LCR and in the flanking region of the cluster of $\beta$-globin genes at the 3'end [24-26]. In another work it was shown that the 5'-in- sulator of the human $\beta$-globin gene domain is capable of transgene protection against position effects. It means that like 5 '-DHS4 of the chicken $\beta$-globin gene domain this insulator bears enhancer-blocking and at the same time barrier activity [27]. In a number of works CTCF-dependent enhancer-blocking elements were reported to play a pivotal role in maintenance and support of imprinting in the Igf2/H19 locus $[28,29]$ and in other imprinted loci of the murine genome [30, 31]. CTCF-dependent enhancer-blocking elements and full-fledged insulators were detected also in a number of genomic domains in different vertebrates [32, 33] and in humans [34].

In the human genome certain tRNA genes [35] and some repeated genomic elements [36-38] are able to display insulator activity along with well-characterized CTCF-dependent insulators.

Further studies of these new types of insulators can substantially enlarge our scope of knowledge of the functional organization of eukaryotic genome.

Mechanism of action of CTCF-dependent enhancer-blocking elements. Though by now enhancer-blocking elements have been studied for quite a long period of time the mechanism of their action remains unknown. This lack of information is largely attributed to the fact that the mechanism of enhancer activity so far as well is only a subject for discussion. There are at least 


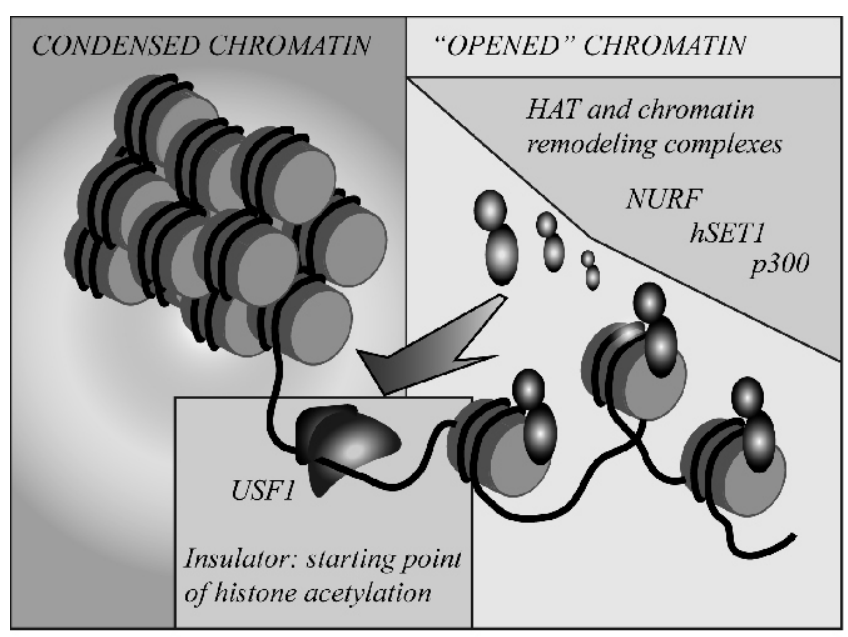

Fig. 3. Barrier function of insulator. USF1, bound to DNA within the chicken beta-globin 5'-insulator, attracts HAT and chromatin remodeling complexes (hSET1, NURF, p300). Thus insulator can constitute a starting point for histone acetylation which prevents spreading of condensed chromatin along the chromosome

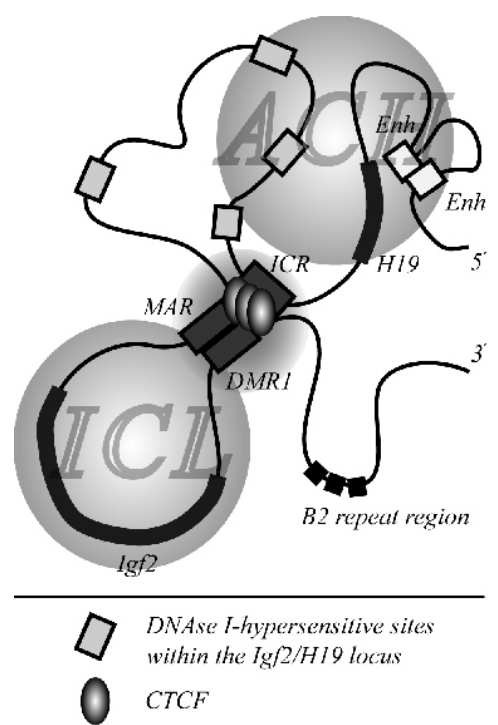

Fig. 4. Spatial interactions within $I g f 2 / H 19$ locus. CTCF participates in pairing of ICR with DMR1 (Differentially Methylated Region 1), and MAR (Matrix Attachment Region) within the maternal allele which forms a chromatin loop containing gene $\operatorname{Ig} f 2$. Such configuration prevents activation of $I g f 2$-promoter by distal enhancers $(E n h) ; A C H-$ active chromatin hub; $I C L$ - inactive chromatin loop

three most popular models which though cannot be considered as alternative. One of these models postulates that enhancer with associated proteins physically interacts with promoter facilitating the preinitiation complex formation and/or driving one of the following stages of initiation of productive transcription. Meanwhile enhancer and promoter are pulled together with the help of free or this-or-that way guided diffusion through the nucleoplasm. This model is confirmed first of all with the data obtained using chromosome conformation capture technique (3C). Indeed, it was demonstrated in a number of model systems that enhancer and the corresponding activated promoter or a group of promoters belong to the same complex. Such complexes were called active chromatin hubs [39-41]. The second model [42] states that enhancer is pulled to the promoter through tracking along the linker part of a chromatin strip. RNA-polymerase II may play the role of a molecular motor in this case. And finally the third model claims that enhancer recruits transcription factors and RNApolymerase II which are then transferred to the promoter [43]. In all three cases an enhancer-blocking element can play a role of a peculiar «trap». Particularly it can substitute a promoter providing an alternative platform for enhancer binding. As a result an alternative loop is formed (enhancer-insulator) [44]. In the same way insulator can substitute a promoter via binding transcription factors and RNA-polymerase II which moves along the chromosome from enhancer to promoter [45]. Thereby, it's appropriate to recall that the well-studied insulator from the chicken $\beta$-globin gene domain is found within the $\mathrm{CpG}$ island which has a certain structural similarity to the promoters of house-keeping genes [16]. Other insulators also have much in common with promoters [46].

Eukaryotic insulators with CTCF-mediated activity can interact with each other supporting the complicated three-dimensional chromatin organization (see below the section «Role of insulators in supporting the three-dimensional genome organization»). Interaction between two insulators can place a gene into a separate chromatin loop which in turn in a number of cases (depending on the loop size) can block enhancer-promoter interactions [47]. For example, such interactions of several CTCF-binding elements inside of the murine imprinted $I g 2 / H 19$ loci (Fig. 4) place the Igf2 gene into a separate loop tearing the connection between the promoter of this gene and the remote enhancer [48]. In classical experiments demonstrating enhancer-blocking activity of SCS elements from Drosophila special genetic constructs were used containing one SCS element placed between enhancer and promoter. Herewith $\mathrm{P}$ element was used as a vector providing single-copy integration of each construct into ectopic genomic positions. In case of eukaryotic cells the easiest way to pla- 
ce genetic constructs into genome is to transfect them with linearized constructs which in the vast majority of cases causes the integration of several copies of one construct into the same genomic position. In order to prevent the activation of a reporter gene with enhancer from the near-by construct the reporter gene itself (or the enhancer) is surrounded by two insulators (Fig. 1, C) [16]. Obviously, in this case the interaction between insulators can place enhancer into an isolated loop of a chromatin fiber.

Mechanism of action of barrier elements. It is usually declared that complete insulators and isolated barrier elements prevent spreading of whatever processive chromatin modifications which lead to formation of both active and inactive chromatin domains. Notwithstanding this fact in the majority of experiments only the ability of barrier elements to block so called position effects was tested. Position effects consist in the suppression of transgene expression when integrated into some heterochromatin region. Classical constitutive heterochromatin is maintained with the help of $\mathrm{H} 3 \mathrm{~K}$ 9-histone methyltransferase and $\mathrm{Hp} 1$ heterochromatin protein. Processive spreading of heterochromatin domain is due to di- and trimethylation of $\mathrm{K} 9$ of histone $\mathrm{H} 3$ recruiting $\mathrm{Hp} 1$ protein which in turn recruits $\mathrm{H} 3 \mathrm{~K} 9$-histone methyltransferase to modify $\mathrm{H} 3$ histone in adjacent nucleosomes [49]. For a certain period of time barrier elements were believed to be a kind of a passive obstacle on the way of heterochromatin domain spreading («traffic jam» model). Most of the described insulators colocalize with DNAse I hypersensitive sites which represent nucleosome-free regions. The sole presence of these nucleosome-free regions could itself prevent the described above processive heterochromatin spreading. Moreover, binding of histone methyltransferase suppressor proteins to these regions might as well be an extra restriction to spreading of heterochromatin [50, 51]. Still it is clear at present that the mechanism of barrier element activity is more complex. The analysis of distribution of the modified forms of histones in different chromatin domains elucidated the fact that the high level of histone acetylation is typical for insulators regardless of the transcription status of the adjacent genomic domains [52]. In ectopic positions insulators produce local domains of hyperacetylated histones [53]. Therefore, the idea of an insulator as just a passive element ceasing any signal transduction («traffic jam» model) does not fit the reality. In practice insulators are spots of nucleation where different enzymatic complexes which are needed for chromatin remodeling and histone modification are assembled. Hyperacetylation of histones $\mathrm{H} 3$ and $\mathrm{H} 4$ and methylation of $\mathrm{K} 4$ of $\mathrm{H} 3$ histone are observed in the region of 5'-insulator (DHS4) of the chicken $\beta$-globin gene domain at all stages of development including the nuclei of elythroid precursors (CFU-E) where transcription of globin genes is not yet activated [54]. Factor USF1 was proved to be indispensable for the onset and further support of these epigenetic modifications in the insulator region $[22,55]$. This factor recruits chromatin remodeling complexes (NURF) (Fig. 3) and enzymes introducing histone modifications typical for the active chromatin sites (hSET1, SET7/9, CBP, p300) [23].

Barrier elements possess one more important activity. They preclude de novo DNA methylation on a promoter coupled to a barrier element [56]. It withdraws the effect of repression imposed by DNA methylation and subsequent binding of the repressor complex Mi2/ $\mathrm{NuRD}$ for transgenes that lack an insulator [53]. This activity has connection neither to histone acetylation nor to transcription and in case of DHS4 of the chicken $\beta$-globin gene domain is provided by the ability of the insulator to recruit protein VEZF-1 which binding sites do not overlap with those of CTCF and USF1 [56]. This activity accounts for the property of insulators to maintain stable expression of transgenes in tissues of transgenic animals. Modern technology for transgenic animal production aids tandem integration of a great number of copies of a transgene-bearing genetic construct into the genome [57]. Like the repeated elements of the genome itself tandem transgene copies are inactivated over time via DNA methylation which inevitably leads to a dramatic decrease of the transgene expression or even to its complete repression. Insertion of insulators into genetic constructs suppresses this effect.

Role of insulators in supporting the three-dimensional genome organization. It has become quite obvious lately that despite the discussed above barrier and enhancer-blocking activities insulators also play an important role in supporting the three-dimensional structure of genome appearing as specific architectural elements. Interactions between remote insulators lead to chromatin loop formation. In these interactions CTCF 
and cohesion play a pivotal role [58-61]. Chromatin looping can lead to various consequences. As it has been described previously a gene placed inside such a loop can be inaccessible for the corresponding activating enhancer. On the other hand, chromatin looping provided by two interacting insulators can assist direct physical contact of promoters and enhancers resulting in transcription activation. This phenomenon has long been known for Drosophila (see [62, 63] for review). There are many reports describing interactions of insulators (CTCF binding sites) which place promoters and enhancers in closer proximity facilitating thereby formation of activator complexes in vertebrates [64-71]. In other cases, as for example in the human Hox gene cluster, the three-dimensional organization of genome supported by CTCF-dependent insulators is essential for gene repression [72]. Participation of insulators in genome 3D structure maintenance can consist also in providing appropriate localization of different genes in certain nuclear compartments, particularly in prilamellar compartment $[65,73]$ which leads to gene repression [74].

The biological role of insulators. After all that has been said about insulators earlier in previous sections the very statement of question about the biological role of insulators might seem a bit surprising. Nonetheless, this question remains quite topical as insulators possess a wide range of biological activities and many of them were tested in model experiments (expression of a reporter gene in some ectopic genomic position). The question of whether these activities are retained in normal genomic positions remains at issue. Among the most studied and well-characterized vertebrate insulators are those at the 5 '- and the 3 '-ends of the $\beta$-globin gene cluster. The role of the enhancer-blocking element at the 5'-end of the locus control region is still quite obscure due to the fact that many regulatory elements forming the active chromatin hub at the $\beta$-globin gene cluster are located behind this enhancer-blocking element $[75,76]$. Similar facts and observations also bring to question the role of the barrier element. Indeed, in murine erythroid cells the region preferably sensitive to DNAse I considerably exceeds in size the $\beta$-globin gene cluster enclosed by insulators. It includes a number of genes of olfactory receptors located in flanking regions at the $5^{\prime}$ - and the 3 '-ends $[77,78]$. In this context the fact that direct deletion of both insulators flanking the murine $\beta$-globin gene domain has no evident biological consequences is not in the least surprising $[79,80]$. At the present time there are no methods for the holegenome analysis of the distribution of enhancer-blocking and barrier elements. The only data available for the analysis thereby is the distribution of CTCF binding sites in the genome. From 15000 to $25000 \mathrm{CTCF}$ binding sites were identified in different cell types of which $45 \%$ were located inside the intergenic regions and $30 \%$ were located inside the gene borders [81, 82]. Comparison of genomic distribution of CTCF-binding sites and the distribution of different histone modifications led to the conclusion that a special class of CTCFbinding sites exists which colocalize with the border regions of chromatin domains [83]. The significance of this observation is not clear yet as CTCF is not at all indispensable for the activity of barrier elements [19].

The most sustained and clear function of insulators so far is imprinting maintenance [84]. In this case the most crucial is the ability of insulators to fold chromatin into loops [60, 85-87]. Other cases where the biological role of insulators is well-understood always keep to chromatin loop formation $[66,71,88,89]$. Therefore, it is quite possible that the main function of vertebrate insulators is to support the three-dimensional architecture of the genome.

Acknowledgements. This work was supported by the Ministry of Science and Education of the Russian Federation (contracts 16.740.11.0353, 14.740.12.1344 and 16.740.11.0483), by Russian Foundation for Support of Basic Researches (grants 11-04-00361-a and 11-04-91334-NNIO_a), by the Presidium of the Russian Academy of Sciences (grants from the Program on Molecular and Cellular Biology) and by a grant of President of the Russian Federation for young scientists (MK-3813.2012.4).

\section{С. В. Ульянов, О. Н. Маркова, О. А. Гаврилов, С. В. Разін}

Інсулятори ссавців: регуляторні механізми і структура хроматину Резюме

Інсулятори було відкрито як геномні елементи, здатні переривати зв'язок між промотором і енхансером (активність, яка блокує функиіонування енхансера), та обмежувати поширення гетерохроматину (бар'єрна активність). У дрозофіли існує декілька типів інсуляторів, які працюють із залученням різних білків. Всі описані інсулятори у ссавичів працюють за участі багатофункиіонального транскрипиійного фактора СТCF. Біологічні функиії інсуляторів ссавців не до кіния з'ясовані. Хоча багато хто вважає, 
щзо вони розмежовують хроматинові домени, прямих свідчень цьому практично немає. Найпоказовішою є участь інсуляторів у роботі центрів встановлення імпринтингу (imprinting choice regions). Результати низки недавно опублікованих робіт свідчать про те, що для встановлення імпринтингу суттєвим є вбудовування інактивованого гена в окремий топологічний домен (петлю). $B$ цьому та в багатьох інших випадках інсулятори працюють як архітектурні елементи, які підтримують тривимірну організацію геному. Взаємодія між парами інсуляторів, уяких поряд з СТCF істотну роль відіграє когезин, організує геном у різного роду петлі.

Ключові слова: хроматиновий домен, бар 'єрний елемент, енхансер-блокуючий елемент, CTCF, імпринтинг.

\section{С. В. Ульянов, Е. Н. Маркова, А. А. Гаврилов, С. В. Разин}

Инсуляторы позвоночных животных: регуляторные механизмы и структура хроматина.

\section{Резюме}

Инсуляторы были открыты как геномные элементы, способные прерывать связь между промотором и энхансером (энхансерблокирующая активность) и ограничивать распространение гетерохроматина (барьерная активность). У дрозофиль существует несколько типов инсуляторов, работающих посредством привлечения различных белков. Все описанные инсуляторы у позвоночных животных работают при участии многофункционального транскрипиионного фактора CTCF. Биологические функиии инсуляторов позвоночных животных не вполне ясны. Хотя принято считать, что они разграничивают хроматиновые домены, прямых свидетельств этому практически нет. Наиболее показательным является участие инсуляторов в работе иентров установления импринтинга (imprinting choice regions). Результаты ряда недавно опубликованных работ свидетельствуют о том, что для установления импринтинга существенным является встраивание инактивированного гена в отдельный топологический домен (петлю). В этом и многих других случаях инсуляторы работают в качестве архитектурных элементов, поддерживающих трехмерную организаиию генома. Взаимодействие между парами инсуляторов, в котором наряду с СТCF значительную роль играет когезин, организует геном в различного рода петли.

Ключевые слова: хроматиновый домен, барьерный элемент, энхансер-блокирующий элемент, CTCF, импринтинг.

\section{REFERENCES}

1. Kellum R., Schedl P. A group of scs elements function as boundaries in enhancer-blocking assay // Mol. Cell. Biol.-1992.-12, N 5.-P. 2424-2431.

2. Kellum R., Schedl P. A position-effect assay for boundaries of higher order chromosomal domains // Cell.-1991.-64, N 5.P. 941-950.

3. West A. G., Gaszner M., Felsenfeld G. Insulators: many functions, many mechanisms // Genes Dev.-2002.-16, N 3.-P. 271-288.

4. Udvardy A., Maine S., Schedl P. The 87A7 chromomere. Identification of novel chromatin structures flanking the heat shock locus that may define the boundaries of higher order domains // J. Mol. Biol.-1985.-185, N 2.-P. 341-358.

5. Recillas-Targa F., Bell A. C., Felsenfeld G. Positional enhancerblocking activity of the chicken beta-globin insulator in transiently transfected cells // Proc. Natl Acad. Sci. USA.-1999.-96, N 25.-P. 14354-14359.

6. Brasset E., Vaury C. Insulators are fundamental components of the eukaryotic genomes // Heredity (Edinb).-2005.-94, N 6.P. 571-576.
7. Bell A. C., Felsenfeld G. Stopped at the border: boundaries and insulators // Curr. Opin. Genet. Dev.-1999.-9, N 2.-P. 191-198.

8. Bell A. C., West A. G., Felsenfeld G. Insulators and boundaries: versatile regulatory elements in the eukaryotic genome // Science.-2001.-291, N 5503-P. 447-450.

9. Felsenfeld G., Burgess-Beusse B., Farrell C., Gaszner M., Ghirlando R., Huang S., Jin C., Litt M., Magdinier F., Mutskov V., Nakatani Y., Tagami H., West A., Yusufzai T. Chromatin boundaries and chromatin domains // Cold Spring Harb. Symp. Quant. Biol.-2004.-69.-P. 245-250.

10. Wallace J. A., Felsenfeld $G$. We gather together: insulators and genome organization // Curr. Opin. Genet. Dev.-2007.-17, N 5.P. 400-407.

11. Lunyak V. V. Boundaries. Boundaries... Boundaries??? // Curr. Opin. Cell Biol.-2008.-20, N 3.-P. 281-287.

12. Chung J. H., Whiteley M., Felsenfeld G. A 5' element of the chicken beta-globin domain serves as an insulator in human erythroid cells and protects against position effect in Drosophila // Cell.-1993.-74, N 3.-P. 505-514.

13. Pikaart M. J., Recillas-Targa F., Felsenfeld G. Loss of transcriptional activity of a transgene is accompanied by DNA methylation and histone deacetylation and is prevented by insulators // Genes Dev.-1998.-12, N 18.-P. 2852-2862.

14. Recillas-Targa F., Pikaart M. J., Burgess-Beusse B., Bell A. C., Litt M. D., West A. G., Gaszner M., Felsenfeld G. Position-effect protection and enhancer blocking by the chicken beta-globin inslator are separable activities // Proc. Natl Acad. Sci. USA.2002.-99, N 10.-P. 6883-6888.

15. Rincon-Arano H., Furlan-Magaril M., Recillas-Targa F. Protection against telomeric position effects by the chicken cHS4 beta-globin insulator // Proc. Natl Acad. Sci. USA.-2007.-104, N 35.-P. 14044-14049.

16. Chung J. H., Bell A. C., Felsenfeld G. Characterization of the chicken beta-globin insulator // Proc. Natl Acad. Sci. USA.-1997.94, N 2.-P. 575-580.

17. Arumugam P. I., Urbinati F., Velu C. S., Higashimoto T., Grimes H. L., Malik P. The 3 ' region of the chicken hypersensitive site-4 insulator has properties similar to its core and is required for full insulator activity // PLoS ONE.-2009.-4, N 9.-P. e6995.

18. Reitman M., Lee E., Westphal H., Felsenfeld G. Site-independent expression of the chicken beta ${ }^{\mathrm{A}}$-globin gene in transgenic mice // Nature.-1990.-348, N 6303.-P. 749-752.

19. Bell A. C., West A. G., Felsenfeld G. The protein CTCF is required for the enhancer-blocking activity of vertebrate insulators // Cell.-1999.-98, N 3.-P. 387-396.

20. Wendt K. S., Yoshida K., Itoh T., Bando M., Koch B., Schirghuber E., Tsutsumi S., Nagae G., Ishihara K., Mishiro T., Yahata K., Imamoto F., Aburatani H., Nakao M., Imamoto N., Maeshima K., Shirahige K., Peters J. M. Cohesin mediates transcriptional insulation by CCCTC-binding factor // Nature.-2008.-451, N 7180.P. 796-801.

21. Xiao T., Wallace J., Felsenfeld G. Specific sites in the C terminus of CTCF interact with the SA2 subunit of the cohesin complex and are required for cohesin-dependent insulation activity // Mol. Cell. Biol.-2011.-31, N 11.-P. 2174-2183.

22. Huang S., Li X., Yusufzai T. M., Qiu Y., Felsenfeld G. USF1 recruits histone modification complexes and is critical for maintenance of a chromatin barrier // Mol. Cell. Biol.-2007.-27, N 22.P. 7991-8002.

23. Li X., Wang S., Li Y., Deng C., Steiner L. A., Xiao H., Wu C., Bungert J., Gallagher P. G., Felsenfeld G., Qiu Y., Huang S. Chromatin boundaries require functional collaboration between the hSET1 and NURF complexes // Blood.-2011.-118, N 5.-P. 13861394. 
24. Farrell C. M., West A. G., Felsenfeld G. Conserved CTCF insulator elements flank the mouse and human beta-globin loci // Mol. Cell. Biol.-2002.-22, N 11.-P. 3820-3831.

25. Li Q., Stamatoyannopoulos G. Hypersensitive site 5 of the human beta locus control region functions as a chromatin insulator // Blood.-1994.-84, N 5.-P. 1399-1401.

26. Tanimoto K., Liu Q., Bungert J., Engel J. D. Effects of altered gene order or orientation of the locus control region on human beta-globin gene expression in mice // Nature.-1999.-398, N 6725.P. 344-348

27. Li Q., Zhang M., Han H., Rohde A., Stamatoyannopoulos G. Evidence that DNase I hypersensitive site 5 of the human betaglobin locus control region functions as a chromosomal insulator in transgenic mice // Nucleic Acids Res.-2002.-30, N 11.P. 2484-2491.

28. Bell A. C., Felsenfeld $G$. Methylation of a CTCF-dependent boundary controls imprinted expression of the Igf2 gene // Nature.-2000.-405, N 6785.-P. 482-485.

29. Hark A. T., Schoenherr C. J., Katz D. J., Ingram R. S., Levorse J. M., Tilghman S. M. CTCF mediates methylation-sensitive enhancer-blocking activity at the H19/Igf2 locus // Nature.2000.-405, N 6785.-P. 486-489.

30. Kanduri C., Fitzpatrick G., Mukhopadhyay R., Kanduri M., Lobanenkov V., Higgins M., Ohlsson R. A differentially methylated imprinting control region within the Kcnql locus harbors a methylation-sensitive chromatin insulator // J. Biol. Chem.-2002.277, N 20.-P. 18106-18110.

31. Fitzpatrick G. V., Pugacheva E. M., Shin J. Y., Abdullaev Z., Yang $Y$., Khatod K., Lobanenkov V. V., Higgins M. J. Allele-specific binding of CTCF to the multipartite imprinting control region KvDMR1 // Mol. Cell. Biol.-2007.-27, N 7.-P. 2636-2647.

32. Valadez-Graham V., Razin S. V., Recillas-Targa F. CTCF-dependent enhancer blockers at the upstream region of the chicken alpha-globin gene domain // Nucleic Acids Res.-2004.-32, N 4.-P. 1354-1362.

33. Zhong X. P., Krangel M. S. Enhancer-blocking activity within the DNase I hypersensitive site 2 to 6 region between the TCR alpha and Dadl genes // J. Immunol.-1999.-163, N 1.-P. 295-300.

34. Filippova G. N., Thienes C. P., Penn B. H., Cho D. H., Hu Y. J., Moore J. M., Klesert T. R., Lobanenkov V. V., Tapscott S. J. CTCF-binding sites flank CTG/CAG repeats and form a methylation-sensitive insulator at the DM1 locus // Nat. Genet.-2001.28, N 4.-P. 335-343.

35. RaabJ. R., Chiu J., Zhu J., Katzman S., Kurukuti S., Wade P. A., Haussler D., Kamakaka R. T. Human tRNA genes function as chromatin insulators // EMBO J.-2011.-31, N 2.-P. 330-350.

36. Roman A. C., Gonzalez-Rico F. J., Fernandez-Salguero P. M. B1-SINE retrotransposons: establishing genomic insulatory networks // Mob. Genet. Elements.-2011.-1, N 1.-P. 66-70.

37. Lunyak V.V., Prefontaine G. G., Nunez E., Cramer T., Ju B. G., Ohgi K. A., Hutt K., Roy R., Garcia-Diaz A., Zhu X., Yung Y., Montoliu L., Glass C. K., Rosenfeld M. G. Developmentally regulated activation of a SINE B2 repeat as a domain boundary in organogenesis // Science.-2007.-317, N 5835.-P. 248-251.

38. Willoughby D. A., Vilalta A., Oshima R. G. An Alu element from the $K 18$ gene confers position-independent expression in transgenic mice // J. Biol. Chem.-2000.-275, N 2.-P. 759-768.

39. de Laat W., Grosveld F. Spatial organization of gene expression: the active chromatin hub // Chromosome Res.-2003.-11, N 5.-P. 447-459.

40. Kooren J., Palstra R. J., Klous P., Splinter E., von Lindern M., Grosveld $F$., de Laat $W$. Beta-globin active chromatin Hub formation in differentiating erythroid cells and in p45 NF-E2 knock-out mice // J. Biol. Chem.-2007.-282, N 22.-P. 1654416552.
41. Gavrilov A. A., Razin S. V. Spatial configuration of the chicken alpha-globin gene domain: immature and active chromatin hubs // Nucleic Acids Res.-2008.-36, N 14.-P. 4629-4640.

42. Zhu X., Ling J., Zhang L., Pi W., Wu M., Tuan D. A facilitated tracking and transcription mechanism of long-range enhancer function // Nuceic Acids Res.-2007.-35, N 16.-P. 5532-5544.

43. Herendeen D. R., Kassavetis G. A., Geiduschek E. P. A transcriptional enhancer whose function imposes a requirement that proteins track along DNA // Science.-1992.-256, N 5061.P. 1298- 1303

44. Hou C., Zhao H., Tanimoto K., Dean A. CTCF-dependent enhancer-blocking by alternative chromatin loop formation // Proc. Natl Acad. Sci. USA.-2008.-105, N 51.-P. 20398-20403.

45. Zhao H., Dean A. An insulator blocks spreading of histone acetylation and interferes with RNA polymerase II transfer between an enhancer and gene // Nucleic Acids Res.-2004.-32, N 16.P. 4903-4919.

46. Raab J. R., Kamakaka R. T. Insulators and promoters: closer than we think // Nat. Rev. Genet.-2010.-11, N 6.-P. 439-446.

47. Tokuda N., Sasai M., Chikenji G. Roles of DNA looping in enhancer-blocking activity // Biophys. J.-2011.-100, N 1.-P. 126134.

48. Kurukuti S., Tiwari V. K., Tavoosidana G., Pugacheva E., Murrell A., Zhao Z., Lobanenkov V., Reik W., Ohlsson R. CTCF binding at the $H 19$ imprinting control region mediates maternally inherited higher-order chromatin conformation to restrict enhancer access to Igf2 // Proc. Natl Acad. Sci. USA.-2006.-103, N 28.-P. 10684-10689.

49. Danzer J. R., Wallrath L. L. Mechanisms of HP1-mediated gene silencing in Drosophila // Development.-2004.-131, N 15.P. 3571-3580

50. Bi X., Broach J. R. UASrpg can function as a heterochromatin boundary element in yeast // Genes Dev.-1999.-13, N 9.P. 1089-1101.

51. Ferrari S., Simmen K. C., Dusserre Y., Muller K., Fourel G., Gil$\operatorname{son} E$., Mermod N. Chromatin domain boundaries delimited by a histone-binding protein in yeast // J. Biol. Chem.-2004.-279, N 53.-P. 55520-55530.

52. Litt M. D., Simpson M., Recillas-Targa F., Prioleau M. N., Felsenfeld $G$. Transitions in histone acetylation reveal boundaries of three separately regulated neighboring loci // EMBO J.-2001.20, N 9.-P. 2224-2235.

53. Mutskov V. J., Farrell C. M., Wade P. A., Wolffe A. P., Felsenfeld $G$. The barrier function of an insulator couples high histone acetylation levels with specific protection of promoter DNA from methylation // Genes Dev.-2002.-16, N 12.-P. 1540-1554.

54. Prioleau M. N., Gendron M. C., Hyrien O. Replication of the chicken beta-globin locus: early-firing origins at the 5' HS4 insulator and the rho- and beta ${ }^{\mathrm{A}}$-globin genes show opposite epigenetic modifications // Mol. Cell. Biol.-2003.-23, N 10.-P. 35363549.

55. West A. G., Huang S., Gaszner M., Litt M. D., Felsenfeld G. Recruitment of histone modifications by USF proteins at a vertebrate barrier element // Mol. Cell.-2004.-16, N 3.-P. 453-463.

56. Dickson J., Gowher H., Strogantsev R., Gaszner M., Hair A., Felsenfeld $G$., West $A$. G. VEZF1 elements mediate protection from DNA methylation // PLoS Genet.-2010.-6, N 1.-e1000804.

57. Goldman I. L., Kadulin S. G., Razin S. V. Transgenic animals in medicine: integration and expression of foreign genes, theoretical and applied aspects // Med. Sci. Monit.-2004.-10, N 11.RA274-285.

58. Parelho V., Hadjur S., Spivakov M., Leleu M., Sauer S., Gregson H. C., Jarmuz A., Canzonetta C., Webster Z., Nesterova T., Cobb B. S., Yokomori K., Dillon N., Aragon L., Fisher A. G., Merkenschlager $M$. Cohesins functionally associate with CTCF 
on mammalian chromosome arms // Cell.-2008.-132, N 3.P. 422-433.

59. Hadjur S., Williams L. M., Ryan N. K., Cobb B. S., Sexton T., Fraser P., Fisher A. G., Merkenschlager M. Cohesins form chromosomal cis-interactions at the developmentally regulated IFNG locus // Nature.-2009.-460, N 7253.-P. 410-413.

60. Nativio R., Wendt K. S., Ito Y., Huddleston J. E., Uribe-Lewis S., Woodfine K., Krueger C., Reik W., Peters J. M., Murrell A. Cohesin is required for higher-order chromatin conformation at the imprinted IGF2-H19 locus // PLoS Genet.-2009.-5, N 11.e1000739.

61. Majumder P., Gomez J. A., Chadwick B. P., Boss J. M. The insulator factor CTCF controls MHC class II gene expression and is required for the formation of long-distance chromatin interactions // J. Exp. Med.-2008.-205, N 4.-P. 785-798.

62. Yang J., Corces V. G. Chromatin insulators: a role in nuclear organization and gene expression // Adv. Cancer Res.-2011.-110.P. 43-76.

63. Yang J., Corces V. G. Insulators, long-range interactions, and genome function // Curr. Opin. Genet. Dev.-2012.-22, N 2.P. 79-85.

64. Krivega I., Dean A. Enhancer and promoter interactions-long distance calls // Curr. Opin. Genet. Dev.-2012.-22, N 2.P. 86-92.

65. Handoko L., Xu H., Li G., Ngan C. Y., Chew E., Schnapp M., Lee C. W., Ye C., Ping J. L., Mulawadi F., Wong E., Sheng J., Zhang Y., Poh T., Chan C. S., Kunarso G., Shahab A., Bourque G., Cacheux-Rataboul V., Sung W. K., Ruan Y., Wei C. L. CTCF-mediated functional chromatin interactome in pluripotent cells // Nat. Genet.-2011.-43, N 7.-P. 630-638.

66. Mishiro T., Ishihara K., Hino S., Tsutsumi S., Aburatani H., Shirahige K., Kinoshita Y., Nakao M. Architectural roles of multiple chromatin insulators at the human apolipoprotein gene cluster // EMBO J.-2009.-28, N 9.-P. 1234-1245.

67. Hou C., Dale R., Dean A. Cell type specificity of chromatin organization mediated by CTCF and cohesin // Proc. Natl Acad. Sci. USA.-2010.-107, N 8.-P. 3651-3656.

68. Majumder P., Boss J. M. Cohesin regulates MHC class II genes through interactions with MHC class II insulators // J. Immunol.-2011.-187, N 8.-P. 4236-4244.

69. Majumder P., Boss J. M. CTCF controls expression and chromatin architecture of the human major histocompatibility complex class II locus // Mol. Cell. Biol.-2010.-30, N 17.-P. 42114223.

70. Chien R., Zeng W., Kawauchi S., Bender M. A., Santos R., Gregson H. C., Schmiesing J. A., Newkirk D. A., Kong X., Ball A. R., Calof A. L., Lander A. D., Groudine M. T., Yokomori K. Cohesin mediates chromatin interactions that regulate mammalian beta-globin expression // J. Biol. Chem.-2011.-286, N 20.-P. 1787017878 .

71. Sekimata M., Perez-Melgosa M., Miller S. A., Weinmann A. S., Sabo P. J., Sandstrom R., Dorschner M. O., Stamatoyannopoulos J. A., Wilson C. B. CCCTC-binding factor and the transcription factor T-bet orchestrate $\mathrm{T}$ helper 1 cell-specific structure and function at the interferon-gamma locus // Immunity.-2009.-31, N 4.-P. 551-564.

72. Ferraiuolo M. A., Rousseau M., Miyamoto C., Shenker S., Wang X. Q., Nadler M., Blanchette M., Dostie J. The three-dimensional architecture of Hox cluster silencing // Nucleic Acids Res.2010.-38, N 21.-P. 7472-7484.

73. Ottaviani A., Schluth-Bolard C., Rival-Gervier S., Boussouar A., Rondier D., Foerster A. M., Morere J., Bauwens S., Gazzo S., Callet-Bauchu E., Gilson E., Magdinier F. Identification of a perinuclear positioning element in human subtelomeres that re- quires A-type lamins and CTCF // EMBO J.-2009.-28, N 16.P. 2428-2436.

74. Reddy K. L., Zullo J. M., Bertolino E., Singh H. Transcriptional repression mediated by repositioning of genes to the nuclear lamina // Nature.-2008.-452, N 7184.-P. 243-247.

75. Tolhuis B., Palstra R. J., Splinter E., Grosveld F., de Laat W. Looping and interaction between hypersensitive sites in the active beta-globin locus // Mol. Cell.-2002.-10, N 6.-P. 1453-1465.

76. Razin S. V., Farrell C. M., Recillas-Targa F. Genomic domains and regulatory elements operating at the domain level // Int. Rev. Cytol.-2003.-226.-P. 63-125.

77. Bulger M., Bender M., Farrell C., Felsenfeld G., Wertman B., Groudine M., Hardison R. Open chromatin domain of mammalian $\beta$-globin genes // Blood Cells Mol. Dis.-2000.-26, N 5.P. 490.

78. Bulger M., Bender M. A., van Doorninck J. H., Wertman B., Farrell C. M., Felsenfeld G., Groudine M., Hardison R. C. Comparative structural and functional analysis of the olfactory receptor genes flanking the human and mouse $\beta$-globin gene clusters // Proc. Natl Acad. Sci. USA.-2000.-97, N 26.-P. 14560-14565.

79. Bender M. A., Byron R., Ragoczy T., Telling A., Bulger M., Groudine M. Flanking HS-62.5 and 3' HS1, and regions upstream of the LCR, are not required for $\beta$-globin transcription // Blood.-2006.-108, N 4.-P. 1395-1401.

80. Bender M. A., Reik A., Close J., Telling A., Epner E., Fiering S., Hardison R., Groudine M. Description and targeted deletion of 5 ' hypersensitive site 5 and 6 of the mouse beta-globin locus control region // Blood.-1998.-92, N 11.-P. 4394-4403.

81. Kim T. H., Abdullaev Z. K., Smith A. D., Ching K. A., Loukinov D. I., Green R. D., Zhang M. Q., Lobanenkov V. V., Ren B. Analysis of the vertebrate insulator protein CTCF-binding sites in the human genome // Cell.-2007.-128, N 6.-P. 1231-1245.

82. Jothi R., Cuddapah S., Barski A., Cui K., Zhao K. Genome-wide identification of in vivo protein-DNA binding sites from ChIPSeq data // Nucleic Acids Res.-2008.-36, N 16.-P. 5221-5231.

83. Cuddapah S., Jothi R., Schones D. E., Roh T. Y., Cui K., Zhao K. Global analysis of the insulator binding protein CTCF in chromatin barrier regions reveals demarcation of active and repressive domains // Genome Res.-2009.-19, N 1.-P. 24-32.

84. Ideraabdullah F. Y., Vigneau S., Bartolomei M. S. Genomic imprinting mechanisms in mammals // Mutat. Res.-2008.-647, N 1-2.-P. 77-85.

85. Murrell A. Setting up and maintaining differential insulators and boundaries for genomic imprinting // Biochem. Cell Biol.-2011.89, N 5.-P. 469-478.

86. Court F., Baniol M., Hagege H., Petit J. S., Lelay-Taha M. N., Carbonell F., Weber M., Cathala G., Forne T. Long-range chromatin interactions at the mouse $\mathrm{Ig}$ f2/H19 locus reveal a novel paternally expressed long non-coding RNA // Nucleic Acids Res.-2011.-39, N 14.-P. 5893-5906.

87. Zlatanova J., Caiafa P. CCCTC-binding factor: to loop or to bridge // Cell Mol. Life Sci.-2009.-66, N 10.-P. 1647-1660.

88. Guo C., Yoon H. S., Franklin A., Jain S., Ebert A., Cheng H. L., Hansen E., Despo O., Bossen C., Vettermann C., Bates J. G., Richards N., Myers D., Patel H., Gallagher M., Schlissel M. S., Murre C., Busslinger M., Giallourakis C. C., Alt F. W. CTCFbinding elements mediate control of $\mathrm{V}(\mathrm{D}) \mathrm{J}$ recombination // Nature.-2011.-477, N 7365.-P. 424-430.

89. Dean $A$. In the loop: long range chromatin interactions and gene regulation // Brief. Funct. Genomics.-2011.-10, N 1.-P. 3-10.

Received 12.01.12 